Volume 3 No. 1, Juni 2018

P ISSN 2442-594X | E ISSN 2579-5708

http://journal.iainlangsa.ac.id/index.php/tibyan

DOI: $10.32505 /$ tibyan.v3i1.474

\title{
POTRET STUDI ALQURAN DI MATA ORIENTALIS
}

Portrait Of The Qur'anic Studies In Oriental's View

\author{
Hasani Ahmad Said \\ Fakultas Ushuluddin UIN Syarif Hidayatullah Jakarta \\ hasaniahmadsaid@uinjkt.ac.id
}

\begin{abstract}
Before the mid-19th century, most of the books written by western people attacked Islam based on purely theological reasons of Christian dogma. Through the study of Orientalism, the West tries to understand Islam in order to destroy it from the inside and thwart every effort to revive Islamic civilization. It sounds provocative, but that is the reality. Orientalist asks Omar Ibn Khattab who fear the verse of Holy Qur'an lost, after large number of memorizer of Holy Quran died in the war of Yamama. The Evidence of the anxiety shown with insisting $\mathrm{Abu}$ Bakr as a Caliph to instantly codify the Quran. In addition, for example, why the writings that shaped suhoof is not directly saved by the prophet himself, and why did the Zayd Ibn Thabit which was appointed as a codification writer of the Quran seemed unprepared with the loss of some verses from surah Bara'ah. Then this paper is to answer the debate in the sight of orientalists.
\end{abstract}

Keywords: studies of The Quran, orientalists

\begin{abstract}
Abstrak
Sebelum pertengahan abad ke-19 sebagian besar buku yang ditulis oleh orang-orang Barat menyerang Islam berdasarkan alasan-alasan teologis murni dari dogma Kristen. Lewat studi orientalisme, Barat mencoba untuk memahami Islam agar dapat dihancurkan dari dalam dan menggagalkan setiap usaha untuk membangkitkan kembali peradaban Islam.Memang terkesan berlebihan bahkan terkesan provokatif, tetapi seperti itulah pada kenyataannya. Bagi orientalis mempertanyakan sebuah kegelisahan 'Umar bin Khattab yang ketakutan akan lenyapnya ayat-ayat suci Alquran, setelah banyaknya para penghafal Alquran wafat pada perang Yamamah. Bukti kegelisahan Umar itu, diluapkan dengan mendesak Abu Bakar yang ketika itu menjadi khalifah untuk segera mengkodifikasikan Alquran. Selain itu, misalnya kenapa tulisan-tulisan yang berbentuk suhuf tidak langsung disimpan sendiri oleh Nabi, dan kenapa pula Zayd bin Thabit yang ditunjuk sebagai pencatat kodifikasi Alquran seolah tidak siap dengan hilangnya beberapa ayat dari suratBara'ah. Maka tulisan ini menjawab perdebatan menyoal Alquran di mata orientalis.
\end{abstract}

Kata Kunci: StudiAlquran, Orientalis 


\section{Pendahuluan}

Mengupas orientalisme dalam studi Islam, akan selalu menarik dan seolah tidak akan kehabisan bahasan karena begitu besarnya cakupan garapan orientalis. Penulis bisa mengatakan bahwa hampir setiap bidang Islamic Studies berkaitan dengan orientalisme, baik itu tafsir, hadis, fikih, filsafat, sufisme maupun sejarah.Masingmasing bidang studi itu tidak luput dari sentuhan kajian para orientalis, bahkan mereka berhasil menghasilkan karya-karya bermutu yang tidak dapat dilakukan oleh sebagian umat Islam. Di situ pula kita akan memahami bagaimana cara Barat memandang Islam.

Hal ini dikarenakan Islam adalah satu dari sekian banyak peradaban yang mampu menjadi lawan tangguh bagi ateisme dan materialisme dalam budaya Barat modern, yang tanpa mengenal rasa takut, siap menghadapi segala tantangan dalam berbagai bentuknya.Lewat studi orientalisme, Barat mencoba untuk memahami Islam agar dapat dihancurkan dari dalam dan menggagalkan setiap usaha untuk membangkitkan kembali peradaban Islam. ${ }^{1}$

Namun demikian, meskipun terjadi keruntuhan dalam peradaban Islam dan kemunduran telah dialami oleh begitu banyak umat muslim sebagai akibat penerapan ideologi asing, pada kenyataannya Islam masih tetap merupakan kekuatan aktif dan vital di dunia. Tulisan ini coba akan mengupas studi orientalis dalam studi Islam.

\section{Menggali Akar Sejarah Munculnya Orientalisme}

Maryam Jamilah, ${ }^{2}$ menjelaskan bahwaketika kegiatan misionaris Kristen berubah menjadi identik dengan tujuan-tujuan imperialisme Inggris dan Prancis, secara berangsur-angsur penekanannya pun bergeser dari persoalan keagamaan ke persoalan keduniaan (sekular).Dalam jangka waktu lama penekanan yang pertama dan kedua itu tercampur-aduk dan sulit dibedakan. ${ }^{3}$

Gerakan pengkajian ketimuran (oriental studies) diberi nama orientalisme baru abad ke 18, meskipun aktivitas kajian bahasa dan sastra ketimuran (khususnya Islam) telah terjadi jauh sebelumnya. Namun istilah orientalis muncul lebih dulu daripada istilah orientalisme. A.J. Arberry (1905-1969) dalam kajiannya menyebutkan istilah orientalis muncul tahun 1638, yang digunakan oleh seorang anggota gereja Timur (Yunani).Menurutnya orientalis adalah "orang yang mendalami berbagai bahasa dan sastra dunia timur."

\footnotetext{
${ }^{1}$ Lihat lebih lanjut, Kartika Pemilia Lestari, "Sejarah Islam di Mata Orientalis - Studi Kritis terhadap Buku Islam and The West : A Historical Cultural Survey karya Philip K. Hitti" dalam http://www.inpasonline.com

/index.php?option=comcontent \&view=article\&id=1011:sejarah-islam-di-mata-orientalis--studi-kritisterhadap-buku-islam-and-the-west--a-historical

-cultural-survey-karya-philip-k-hitti\&catid=28:sejarah-peradaban islam\& Itemid=97, diakses pada Jumat, 09 November 2012.

${ }^{2}$ Adalah orang Yahudi yang kemudian memeluk Islam dan gigih memerangi orientalis, menulis dalam bukunya yang berjudul Islam and Orientalism. Buku ini kemudian diterjemahkan menjadi Islam dan Orientalisme : Suatu Kajian Analitik.

${ }^{3}$ Maryam Jamilah, Islam dan Orientalisme : Suatu Kajian Analitik (Jakarta : PT. RajaGrafindo Persada, 1994), h. 1.
} 
Secaradisipliner EdwardSaid mendefinisikan orientalis-mesebagai:“...bidang pengetahuanatau ilmu yang mengantar-kan pada [pemahaman] dunia timur secara sistematis sebagai suatu objek yang dapat dipelajari, diungkap, dan diaplikasikan." Jika orientalisme merupakan bidang pengetahuan, maka sudah tentu ia memiliki metode, obyek kajian, teori dan bahkan framework kajiannya sendiri. Namun sebagai suatu disiplin ilmu, sejarahnya tentu diwarnai oleh latar belakang ideologi, agama, kepercayaan masyarakat Barat.Jadi sejarah ilmu orientalisme diwarnai milleu keagamaan, politik dan keilmuan.

Motif keagamaan Barat yang didominasi oleh Kristen memandang Islam sebagai agama yang sejak awal menentang doktrin-doktrinnya.Islam yang misinya menyempurnakan millah sebelumnya telah banyak melontarkan koreksi terhadap agama itu.Islam dianggap "menabur angin" dan lalu menuai badai perseteruan dengan Kristen.Bahkan lebih ekstrim lagi, perseteruan itu ada sejak sebelum Islam datang.Thomas Wright, penulis buku Early Christianity in Arabia; A Historical Essay, mensinyalir perseteruan antara Islam dan Kristen terjadi sejak bala tentara Kristen pimpinan Abrahah menyerang Ka'bah dua bulan sebelum Nabi lahir. Menurutnya, kalau saja tentara Abrahah itu tidak kalah mungkin seluruh jazirah itu berada di tangan Kristen, dan tanda salib sudah terpampang di Ka'bah. Muhammad pun mungkin mati sebagai pendeta.Selain itu perang salib yang berjalan hampir selama dua abad (sejak tahun 1096 hingga tahun 1271) telah cukup menambah milleu perseteruan tersebut.Disaat-saat seperti inilah keingintahuan orang Barat tentang Islam mulai tumbuh. $^{4}$

Perang Salib atau ketika dimulainya pergesekan politik dan agama antara Islam dan Kristen Barat di Palestina. Argumentasi mereka menyatakan bahwa permusuhan politik berkecamuk antara umat Islam dan Kristen selama pemerintahan Nuruddin Zanki dan Shalahuddin al-Ayyubi. Karena kekalahan demi kekalahan yang dialami pasukan Kristen maka semangat membalas dendam tetap membara selama berabadabad.

Hamid Fahmy Zarkasy menyoroti, bahwa Barat mengkaji Timur dan Islamkarena motivasi keagamaan dan politik. ${ }^{5}$ Barat yang di satu sisi mewakili Kristen, memandang Islam sebagai agama yang sejak awal menentang doktrin-dontrinnya.Bahkan ada yang menganggap bahwa perseteruan itu ada sejak sebelum Islam datang.Sedangkan motivasi politik, disebabkan karena Barat menganggap bahwa Islam adalah peradaban yang tersebar dan menguasai peradaban dunia secara cepat.Barat sebagai peradaban yang baru bangkit dari kegelapan melihat Islam sebagai ancaman langsung yang besar bagi kekuasaan politik dan agama mereka.Sedangkan Mohammad al-Bahy meringkas motivasi orientalis itu dalam dua hal, yaitu untuk memperkokoh Imperialisme Barat di

\footnotetext{
${ }^{4}$ Fahmi Zarkasyi, “Tradisi Orientalisme dan Framework Studi Alquran” dalam http://tsaqafah.isid.gontor.ac.id/volume-vii-1/tradisi-orien talisme-dan-framework-studi-al-quran.html”, diakses pada Jumat, 9 November 2012.

${ }^{5}$ Lihat Lebih lanjut, Hamid Fahmy Zarkasy, Mengkritisi Kajian Islam Orientalis, Pengantar, Majalah Islamia, Volume II No. 3, Desember 2005.
} 
negara-negara Islam agar umat Islam rela menerima kekuasaan Barat dan untuk memperkuat jiwa Perang Salib dengan mengatasnamakan kajian ilmiah dan kemanusiaan. ${ }^{6}$

Fakta lainnya adalah bahwa orientalisme muncul untuk kepentingan penjajahan Eropa terhadap negara-negara Arab dan Islam di Timur, Afrika Utara dan Asia Tenggara, serta kepentingan mereka dalam memahami adat istiadat dan agama bangsabangsa jajahan itu demi memperkokoh kekuaaan dan dominasi ekonomi mereka pada bangsa-bangsa jajahan. Faktor-faktor tersebut mendorong mereka menggalakkan studi orientalisme dalam berbagai bentuknya di perguruan-perguruan tinggi dengan perhatian dan bantuan dari pemerintah mereka. ${ }^{7}$

\section{Memaknai Orient, Oriental, Orientalis, dan Orientalisme}

Kata 'Orientalisme' adalah kata yang dinisbatkankepada studi/penelitian yang dilakukan oleh selain orang Timurterhadap berbagai disiplin ilmu ketimuran, baik bahasa, agama,sejarah, dan permasalahan-permasalahan sosio-kultral bangsaTimur.Atau ada juga yang mengatakan bahwa 'Orientalisme'adalah suatu disiplin ilmu yang membahas tentang ketimuran. ${ }^{8}$ Joesoef Sou'yb memahami orientalisme adalah sebuah istilahyang berasal dari kata orient yang secara harfiah berarti timur.

Kata ini secara geografis berarti dunia belahan timur, dan secara etnologis berarti bangsa-bangsa di timur. ${ }^{9}$ Sedangkan oriental adalah sebuah kata sifat yang berarti halhal yang bersifat timur yang cakupannya amat luas.Sementara orientalis adalah ilmuwan Barat yang mendalami masalah-masalah ketimuran, yang di dalamnya tentang bahasa-bahasa,kesusastraan, peradaban dan agama-agama timur. ${ }^{10}$ Melihat beberapa pengertian di atas, dapat disederhanakan bahwa orientalisme adalah tradisi kajian ketimuran dan keislaman di dunia Barat yang telah berabad-abad, yang bersifat ilmiah.

Namun terkadang penamaan orientalis hanya dibatasi kepada orang-orang yang mengkaji pemikiran Islam dan peradabannya. Dengan begitu, orientalisme dimaknai

\footnotetext{
${ }^{6}$ Nuim Hidayat, Imperialisme Baru (Jakarta : Gema Insani Press, 2009), h. 51.

${ }^{7}$ Baca lebih lanjut, Didin Saefuddin Buchori, "Runtuhnya Sendi-Sendi Orientalisme Dalam Kajian Islam", diakses dari http://www.ulil-albab.uika-bogor.ac.id/berita-134-runtuhnya-sendisendiorientalisme-dalam-kajian-islam.html, Jumat, 09 November 2012; Baca pula lebih lanjut, Adian Husaini, "Kajian Orientalis di UIN Jakarta" diakses dari http://insistnet.com/index.php?option=com_content\&view=article\&id=71:kajian-orientalis-di-uinjakarta\&catid=1:adian-husaini, Jumat, 09 November 2012.

${ }^{8}$ Abdurrahman Hasan el-Maidani, Ajnihatu-1 Mukr ats-Tsalasah, (Bayrut, Dâr al-Qalam, 1980 M.), cet. II, h. 83, dikutip dari Hasan Abdul Rauf M. el-Badawiy dan Abdurrahman Ghirah, Orientalisme dan Misionarisme : Menelikung Pola Pikir Umat Islam (Bandung: PT. Remaja Rosdakarya, 2007), h.3.

${ }^{9}$ Joesoef Sou'yb, Orientalisme dan Islam (Jakarta: Bulan Bintang, 1985), h. 1.

${ }^{10}$ Mahmud Hamdi Zaqzuq, al-Istishrâq wa al-Khalfiyyah al-Fikriyyah li al-Sirâ' al-Hadâra (tt: tp, 1988), h. 24.
} 
sebagai satu cara atau sikap mengenai hal-hal yang bersifat Timur, ${ }^{11}$ yang secara terminologis biasanya identik dengan paradigma berpikir, ${ }^{12}$ pembedaan ontologis dan epistemologis yang dibuat antara Timur (the Orient) dan Barat (the Occident). ${ }^{13}$

Dalam perkembangannya, fokus utama kajian orientalis adalah agama Islam dan bahasa Arab, karena keduanya merupakan faktor terbesar dari ketertarikan orientalis disamping gagasan, politik, dan teologi yang mewarnai kehidupan masa kini. ${ }^{14}$ Dalambeberapa kajian,mereka melakukan di bawah proyek besar orientalis dengan menjelajahi dunia Timur.

Dalam kajian-kajian orientalis dengan berbagai diskursus studi keislaman ini, sebenarnya bisa diberi pengertian bahwa mereka adalah orang-orang yang dengan sengaja menyerang keyakinan umat Islam dan mendiskreditkan Islam, sedangkan mempelajari tradisi Islam merupakan topeng ansich. Pengertian ini didasarkan pada peristiwa Perang Salib, dimana bangsa Barat mengalami kekalahan atas bangsa Timur dalam memperebutkan kawasan Palestina, tempat ziarah kaum Nasrani, yang di menangkan tentara Islam pimpinan Salahuddin al-Ayubi (1169-1193). Dari sinilah, orientalis kemudian tertuju kepada penjajahan dunia Islam, dengan berkedok menggali dan mempelajari khazanah Islam, yang muara akhirnya hanyalah untuk menghancurkan Islam. ${ }^{15}$

Hal ini tak lepas dari kesadaran mereka, bahwa Islam tidak bisa diperangi secara fisik sehingga mereka lebih memilih pada perang fikir. Lalu mengapa hadis dijadikan salah satu sasaran empuk mereka, hal ini berawal dari persepsi mereka yang mengatakan bahwa agama yang paling benar adalah agama Yesus bukan Islam, sementara Alquran yang dijadikan pegangan umat Islam bukanlah wahyu. Selanjutnya Muhammad dijadikan referensi, dengan mencari titik kelemahan Muhammad sebagai individu bukan sebagai wahyu atau utusan.Akhirnya, sebagai sumber otoritas kedua mereka-pun menelanjangi hadis, dalam kenyataannya mereka gagal menyerang dan meragukan Alquran.Meminjam istilah Abdul Ra'uf, misi dari orientalis ini adalah penghancuran tradisi (destructio of the tradition). ${ }^{16}$

${ }^{11}$ Tk. H. Ismail Jakub, Orientalisme dan Orientalisten (Surabaya: C.V. Faizan, tt.), h. 11; lihat pula Muhammad Fathullah al-Zayadi, al-Istisyrâq Ahdâfuhu wa Wasâiluhu (Syiria-Libanon: Dâr Qutaibah, 2002), h. 15.

${ }^{12}$ Adnan M. Wizan, Akar Gerakan Orientalisme Dari Perang Fisik Menuju Perang Fikir, terj. Ahmad Rafiq Zainul Mun'im dan Fathurrahman (Yogyakarta: Fajar Pustaka, 2003), h. 1.

${ }^{13}$ Edward W. Said, Orientalisme, terj. Asep Hikmat (Bandung: Pustaka, 1996), h. 3.

${ }^{14}$ Muhammad 'Alawî al-Mâlikî, Mauqifu al-Muslîm min al-Dirâsat al-Istisyrâqiyah (Kairo: Mathba'ah Hasan, tt), h. 6-7; lihat pula Âbir bin Muhammad al-Sufyân, al-Mustasyriqûn wa man Tâbi'ahum wa Maiqufuhum min Stabât al-Syarî’ah wa Syumûlaha Dirasatan wa Tatbiqan (Makkah: Maktabaah al-Manārah, 1988), h. 1-4.

${ }^{15}$ Siti Mahmudah Noorhayatie, "Hadith Di Mata Orientalis (Studi Kritis Atas Pemikiran Ignaz Goldziher Tentang Penulisan Hadith)" diakses dari http://jurnalushuluddin.wordpress.com/, diunduh pada Jumat 09 November 2012.

${ }^{16}$ Hendro Prasetyo, "Pembenaran Orientalisme Kemungkinan dan Batas-batasnya," dalam ISLAMIKA Jurnal Dialog Pemikiran Islam (Bandung: Mizan, 1994), h. 101. 


\section{Orientalisme vis a visStudi Islam antara Misi dan Dogma}

Ali Husny al-Kharbuthly seorang Guru Besar di 'Ain Syams, Mesir, yang dikutip Hamka menyebutkan, bahwa ada tiga tujuan orientalisme di dunia Islam, yaitu (1) Untuk penyebaran agama Kristen ke negeri-negeri Islam, (2) Untuk kepentingan penjajahan, (3) Untuk kepentingan ilmu pengetahuan semata. ${ }^{17}$ Didin Saifudin mengutip pendapat Amien Rais ${ }^{18}$ sekurang-kurangnya terdapat enam dogma orientalisme, yaitu pertama, ada perbedaan mutlak dan perbedaan sistematik antara Barat yang rasional, maju, manusiawi dan superior, dengan Timur yang sesat, irrasional, terbelakang dan inferior. Menurut anggapan mereka, hanya orang Eropa dan Amerika yang merupakan manusia-penuh, sedangkan orang Asia-Afrika hanya bertaraf setengah-manusia.

Edward W Said menyatakan orientalisme memandang Timur sebagai sesuatu yang kebaradaannya tidak hanya disuguhkan melainkan juga tetap tinggal pasti dalam waktu dan tempat bagi Barat.Seluruh periode sejarah budaya, politik dan sosial timur hanyalah dianggap sebagai tanggapan semata-mata terhadap Barat. Barat adalah pelaku (actor),sedangkan Timur hanyalah penanggap (reactor) yang pasif. Barat adalah penonton, penilai dan juri bagi setiapsegi tingkah laku Timur. ${ }^{19}$

Sikap-sikap orientalis kontemporer, lanjut Said, telah menguasai pers dan pikiran masyarakat. Orang-orang Arab, umpamanya, dianggap si hidung belang yang senang menerima suap yang kekayaannya merupakan penghinaan terang-terangan terhadap peradaban sejati.Selalu ada asumsi bahwa meskipun konsumen Barat tergolong mitoritas dari penduduk dunia, mereka berhak untuk memiliki atau membelanjakan sebagian besar sumber daya dunia. Mengapa?Karena mereka manusia-manusia sejati yang berlainan dengan dunia Timur. ${ }^{20}$ Kedua, abstraksi dan teorisasi tentang Timur lebih banyak didasarkan pada teks-teks klasik, dan hal ini lebih diutamakan daripada bukti-bukti nyata dari mayarakat Timur yang konkrit dan riil. Dalam masalah ini, para orientalis tidak bisa mengelakkan tuduhan Edward W Said bahwa mereka tidak mau menyelidiki perubahaan yang terjadi dalam masyarakat Timur, tetapi lebih mengutamakan isi teks-teks kuno sehingga orientalisme berputar-putar di sekitar studi tekstual, tidak realistis. Philiph K. Hitti umpamanya, mengatakan bahwa untuk mempelajari Islam dan umatnya tidak diperlukan kerangka teori baru, karena menurutnya masyarakat Islam yang sekarang sembilan abad yang lalu.

Ketiga, pada dasarnya Timur itu merupakan sesuatu yang perlu ditakuti, atau sesuatu yang perlu ditaklukkan.Apabila seseorang orientalis mempelajari Islam dan umatnya, keempat dogma itu perlu ditambah dengan dua dogma pokok lainnya.Kelima, Alquran bukanlah wahyu Ilahi, melainkan buku karangan Muhammad yang merupakan

\footnotetext{
${ }^{17}$ Hamka, Studi Islam, (Jakarta: Pustaka Panjimas, 1985), hal. 12.

${ }^{18}$ Didin Saefuddin Buchori, "Runtuhnya Sendi-Sendi Orientalisme Dalam Kajian Islam” diakses dari http://www.ulil-albab.uika-bogor.ac.id/berita-134-runtuhnya-sendisendi-orientalisme-dalam-kajianislam.html"; baca lebih lanjut, M. Amien Rais, Cakrawala Islam, Bandung: Mizan, 1986.

${ }^{19}$ Edward W Said, Orientalisme, Terj. Asep Hikmat, (Bandung: Pustaka Salman,1996), h. 143-144

${ }^{20}$ Edward W Said, Orientalisme, h. 143.
} 
gabungan unsur-unsur agama Yahudi, Kristen, dan tradisi Arab pra-Islam.Seorang orientalis bernama Chateaubriand, misalnya, mengindoktrinasi murid-muridnya bahwa Alquran itu sekedar buku karangan Muhammad.Alquran tidak memuat prinsip-prinsip peradaban maupun ajaran yang memperluhur watak manusia.Iabahkan mengatakan, Alquran tidak mengutuk tirani dan tidak menganjurkan cinta pada kemerdekaan.Keenam, kesahihan atau orientisitas semua hadis harus diragukan.Malah ada yang mengeritik syarat-syarat sahihnya hadis seperti yang dilakukan Joseph Schacht.Amien Rais menyindir bahwa disamping ada hadis riwayat Bukhari dan Muslim ada juga "hadis riwayat Josep Schacht".

\section{Mengenal Lebih Dekat Sosok Orientalis: Potret Studi Alquran di Mata Orientalis}

Diskursus Alquran di mata ilmuan Barat dan orientalis selalu menarik untuk diperbincangkan. ${ }^{21}$ Alquran menyatakan dirinya sebagai kitab yang terhindar dari keraguan (lärayba fîh), ${ }^{22}$ dijamin keotentikannya, ${ }^{23}$ dan bahkan sampai saat ini tidak ada kitab tandingannya. ${ }^{24}$ Namun demikian, telah terjadi pergeseran cara pandang dikalangan sarjana terhadap Alquran sejak beberapa dekade terakhir sebelum berakhir abad XX. Huston Smith dalam The World Religions mengatakan bahwa belum pernah ada kitab dalam khazanah kegamaan pada kebudayaan lain yang demikian sulit dimengerti oleh orang barat selain Alquran. ${ }^{25}$ Apabila di masa-masa sebelumnya kitab suci tersebut di pandang secara teologis, fenomena Alquran dari sisi asal usul dari mana ia berasal, maka akhir-akhir ini fenomena tersebut didekati sebagai fenomena independen, sebagai sebuah fakta kultural bukan karena sumber kemunculannya, tetapi karena dirinya sendiri memang bermakna bagi masyarakat.

Di sepanjang sejarah, ada beberapa kalangan yang masuk dalam kategori ini yang diperlakukan sebagai pelaku bid'ah, atau paling tidak diperangi bahkan pahit-pahitnya hukuman mati sebagai imbas terberat. Bagaimanapun juga kedua hukum tersebut memiliki konsekwensi makna yang sama, yakni berupa memojokkan dan menafikan suara yang berbeda. Meskipun tidak dikafirkan, misalnya Muktazilah tidak dapat tum-

${ }^{21}$ Kajian semisal ini pernah penulis lakukan secara serius dan tertuang dalam sub bab karya disertasi S3 penulis di Sekolah Pascasarjana UIN Syarif Hidayatullah. Sub bab itu diberi judul menyoal mun -sabah: respon terhadap kritik ilmuwan barat dan orientalis.Dari penelitian serius inilah membawa penulis menjadi doktor terbaik UIN, tercepat sekaligus termuda pada masanya, tahun 2011. Karya disertasi itu adalah embrio dari pembimbingan dan pengkaderan di Pusat Studi al-Quran yang langsung mendapatkan bimbingan dari mahaguru Prof. Dr. M. Quraish Shihab, M.A. Selanjutnya baca, Hasani Ahmad Said, Diskursus Munasabah Alquran (Jakarta: Puspita Press, 2011), h. 76-107.

${ }^{22}$ Q.S. al-Baqarah/2: 2.

${ }^{23}$ Q.S. al-hijr/19: 9.

${ }^{24}$ Q.S. al-Isrā'/17: 88 .

${ }^{25}$ Ketika Smith membandingkan Alquran, Perjanjian lama, dan Perjanjian Baru, ia memaparkan bahwa Alquran memang lebih komplit meskipun hanya empat perlima panjangnya dari Perjanjian Lama dan Baru.Begitupun sebaliknya, keduanya memiliki kekurangan yang tidak terdapat dalam Alquran, yang kedua kitab suci Yahudi dan Nasrani itu diwahyukan pada tahap-tahap awal dalam perkembangan rohani manusia dan proses penyampaiannya sebagaian telah didistorsi. Lihat, Huston Smith, The World's Religions (Sanfransisko: Harper Collins Publisher, 1991), 268. 
buh subur. ${ }^{26}$ Kecuali belakangan ini, dalam tradisi Islam, termasuk Sunni tidak dapat berdampingan harmonis dengan aliran ini. Bahkan, yang lebih menyedihkan buku-buku yang ditulis oleh mereka, tidak sampai kepada kita karena dibakar atau di bumi hanguskan akibat fanatisme mazhab.

Orientalis atau orientalisme terambil dari kata orient yang berarti timur. Ia adalah ilmu yang membahas tentang bahasa, budaya termasuk agama dan kesusastraan masyarakat Timur. ${ }^{27}$ Meskipun tidak selamanya benar, bisa jadi ada pengecualian. Ini terbukti misalnya, Issa Boullata seorang penganut Kristen asal Palestina dan kini warga Negara Kanada yang sempat juga mengajar diIAIN Jakarta, menyangsikan bahkan mempertanya- kantulisan Najib al-'Aqiqi dalam al-Mustshriqūn yang mencantumkan nama Fazlur Rahman, cendekiawan muslim Pakistan, sebagai salah seorang orientalis. ${ }^{28}$ Perhatian pada spektrum yang lebih luas mengenai serangan orientalis terhadap Alquran dalam berbagai dimensi untuk dapat menyajikan suatu citra beberapa upaya dan tujuan Barat dalam mencemarkan kemurnian teks Alquran. Tampaknya terdapat beberapa pintu gerbang yang digunakan sebagai alat penyerang terhadap teks Alquran, salah satunya menghujat dan meragukan penulisan dan kompilasinya. $^{29}$

Menurut Jeffery sebagaimana dikutip M.M. 'An'am bahwa para ilmuwan Barat tidak sependapat bahwa susunan teks Alquran baik ayat maupun suratnya yang ada di tangan kita sekarang, sama dengan apa yang terdapat pada zaman Nabi Muhammad. ${ }^{30}$ Walaupun sudah diketahui bahwa peristiwa itu diabadikan oleh hadis yang diriwayatkan oleh Imam al-Bukhari yang sudah dikenal kredibilitasnya di bidang hadis, namun ini semua tidak diindahkan bahkan dianggap palsu oleh orientalis.

\footnotetext{
${ }^{26}$ Nasr Hamid Abu Zayd, Al-Quran Hermeneutika dan Kekuasaan, 9-10.

${ }^{27}$ M. Quraish Shihab. “Orientalisme.”Jurnal Studi al-Qur'ân, 1, no. 2(2006): 21.

${ }^{28}$ Lihat lebih lanjut, Najib al-'Aqiqī, al-Mustshriqūn (Mesir: Dār al-Ma'ārif, t.th.), 146. Lihat pula, M. Quraish Shihab.“Orientalisme.” 22.

${ }^{29}$ Ibnu Waraq kelahiran Rajkot, India tahun 1946 dari pasangan keturunan muslim India yang melanjutkan studinya di Universitas Edinburg, Inggris di bawah asuhan langsung tokoh orientalis terkenal, Montgomery Watt menyorot beberapa isu kontroversi yang berhubungan dengan orisinalitas dan otentisitas Alquran. di antara isu itu adalah sebagai berikut: kerancuan gramatika Alquran, dugaan adanya pengurangan dan penambahan ayat, nasikh mansukh dalam Alquran, mengukur validitas Alquran dengan penemuan sains, kelahiran Isa, kekeliruan sejarah (histirical errors) dalam Alquran, cerita Yesus dalam Alquran. selain Ibnu Warraq, Mark A. Gabriel juga banyak menyorot doktrin Alquran tentang jihad, perang, dan hubungan umat Islam dengan Yahudi dan Kristen. Misalnya Gabril membahas surat al-Qitāl sebagai legitimasi perang, Islam adalah teroris, kontradiksi dalam Alquran, dan Alquran memerangi ahl al-Kitab. lihat, Ibn Warraq, The Origins of The Qur'an, Essays on Islam's Holy Book (New York: Prometheus Books, 1998), 110-123, lihat pula Ibnu Warraq, Why I Am Not a Muslim (New York: Prometheus Books, 1995), 111-158. Nasaruddin Umar. “Alquran di Mata Mantan Intelektual Muslim: Ibn Warraq dan Mark A. Gabriel”. Jurnal Studi al-Qur'ân, 1, No. 2 (2006): 87-132.

${ }^{30}$ M.M. Al-'A'am, The History of The Qur'anicText From Revelation to Compilation A Comparative Study The Old and New Testamenth, (Sejarah Teks Al-Qur' Perbandingan dengan Perjanjian Lama dan Perjanjian Baru, terj. Sohirin Solihin et. All.(Jakrta: Gema Insani Press, 2005), 338.Lihat pula Arthur Jeffery, The Textual History of The Qur'an, (diakses 27 April 2010); diambilkan dari http://www.bible.ca/islam/library/Jeffery/thq.htm.
} 
Di masa moderen seperti sekarang ini, gerakan-gerakan itu muncul dan hampir mirip dengan fenomena di atas, baik mengatasnamakan lembaga maupun gerakan perorangan. Hal ini dipengaruhi oleh trend pemikiran yang sedang berkembang, umumnya datang dari pemikir Barat, di luar afiliasi keagamaan. Di awal pergerakan dan pergeserannya trend besar itu muncul secara sadar ataupun tidak, muncul melalui para orientalis. Tetapi pada kenyataannya sekarang, bukan hanya muncul dari kalangan orientalis, tetapi sudah ada percikan dan cikal bakal pemikiran orientalis yang menular kepada para sarjana Muslim yang berupaya "membongkar" Alquran. Badawi dalam penelitiannya menulis ada 294 orientalis. Urutan yang paling pertama, Badawi memasukkan nama Arthur John Arberry (1905-1069) dan posisi terakhir Theodor Willem Juynboll (1866-1048). ${ }^{31}$ Beberapa nama ilmuan barat dan orientalis yang konsen terhadap kajian Alquran misalnya Theodor Nöldeke (1836-1930), Goldziher, Yosep Schat, Flügel, Blachëre, Mingana, Joseph Puin, Richard Bell, W. Montgomery Watt, dan lain-lain. Metodologi yang menarik dari kajian mereka dapat dilihat sebagai balas dendam, partisan dan keji. Maka, Parvez Manzoor menilai orientalis sebagai sesuatu yang frontal, subversif ketika itu, behind the lines, seranganterhadap Alquran. ${ }^{32}$

Bahkan sebelum Theodor Nöldeke ada pula orientalis yang bernama Abraham Geiger. ${ }^{33}$ Ada lima pemikiran yang dikembangkan Geiger yaitu tentang $T$; but, menurutnya bahwa $t$-but bukan berasal dari bahasa Arab murni, tetapi diambil dari bahasa Ibrani; jannatu dan jahannam; rabbani, dan sabt. ${ }^{34}$

Melacak kajian Alquran di Barat telah dimulai sejak abad 12, yang juga merupakan bagian dari orientalisme secara umum. ${ }^{35}$ Montgomery Watt, ${ }^{36}$ memetakan paling tidak ada tiga kajian besar yang mereka perjuangkan. Pertama, karya yang terarah pada kajian kitab suci; ${ }^{37}$ kedua, terjemah atau alih bahasa Alquran; dan ketiga, pemahaman Alquran. Jika melihat betapa banyak karya orientalis yang tersebar,

31 'Abd al-Raman Badawi, Mawsū'ah al-Mustasyriqūn (Bayrut: Dār al-'Ilm al-Maliyūn, 1993).

${ }^{32}$ S. Parvez Manzoor. "Method Vis A Vis Truth: Orientalisme dan Studi al-Qur’ân.” Jurnal Studi alQur'ân 1, no. 2 (2006): 46.

${ }^{33}$ Geiger merupakan salah satu penganut Yahudi, seorang intelektual tokoh sekaligus pendiri Yahudi liberal di Jerman. Geiger mengikuti kompetisi masuk Universitas Bonn tahun 1832 dengan menulis disertasi Was hat Mohammed aus Dem Judenthume Aufgemmen?Diseratsi ini dibaca dan diseleksi oleh Prof. Georg B.F. Freytag dari Fakultas Oriental Studies, Universitas Bonn.Dan hasilnya, Geiger berhasil menang dan mendapat hadiah dari tulisannya.Padahal saat itu usianya baru 22 tahun. Lihat, Adnin Armas, Metodologi Bibel dalam Studi Alquran (Jakarta: Rajawali Grafindo Persada, 1996), 55; lihat pula, Ahmad Farhan, "Orientalisme Alquran: Studi Pemikiran Abraham Geiger" dalam Orientalisme Alquran dan Hadis(Yogyakarta: Nawesea Press, 2007), 57.

${ }^{34}$ Lihat lebih lanjut, Ahmad farhan, "Orientalisme Alquran: Studi Pemikiran Abraham Geiger", 6263.

${ }^{35}$ Lihat, Nur Kholis Setiawan, "Orientalisme Alquran: Dulu, Kini dan Masa Datang, dalam Orientalisme Alquran dan Hadis (Yogyakarta: Nawesea Press, 2007), 1; lihat pula, J.D.J. Waardenburg, "Mustashrikun" dalam C.E. Boswort dan E. Van Donzel (ed.), The Encyclopedia of Islam, (Leiden: E.J. Brill, 1993), 737.

${ }^{36} \mathrm{~W}$. Montgomery Watt, Bell's Introduction to the Qur'an, ( Edinburgh, Edinburg University Press, 2005), 173-178.

${ }^{37}$ Baca misalkan karya Arthur Jeffery, Materials for the History of The Text of The Quran, The Old Codices (Leiden: E.J. Brill, 1937). 
ketiga-tiganya masih menunjukkan semangat dari apa yang diperjuangkannya, namun melihat sisi banyak kajiannya, nampaknya kajian teks sekaligus kritik teks lebih mendominasi dibanding kriteria poin dua dan tiga. Motifnya mereka bermacam, paling tidak ada dua faktor yang melatarbelakngi ketertarikan Barat untuk mengkaji Timur. Yaitu, motif keagamaan, dan motif politik. ${ }^{38}$

Hubungan antara orientalis dan dunia Timur tentu tidak bisa dilepaskan dari perkembangan sejarah hubungan antara dunia Islam dan Kristen sejak permulaan. ${ }^{39}$ Seperti diketahui, hubungan diskursif dan intelektual antara Timur dan Barat sangat diwarnai oleh konteks permusuhan di abad pertengahan, ${ }^{40}$ khususnya pada Perang Salib. ${ }^{41}$ Polemik itu bertujuan menciptakan otentisitas dari keunggulan, dengan mencitrakan Islam sebagai pejoratif, keliru dan penyalahgunaan yang sengaja. ${ }^{42}$ Persentuhan kesarjanaan Barat tentang Alquran pertama kali dilakukan dengan menerjemahkan Alquran ke bahasa-bahasa Barat. ${ }^{43}$

Melacak tradisi awal orientalis yang berkonsentrasi dalam penyusunan Alquran berdasarkan kronologi turunnya surat-surat, disinyalir telah ada sejak pertengahan abad ke-19. Bahkan jauh sebelum itu, al-Baha menduga embrio orientalisme sudah ada pada abad XIII M. Hal ini ditandai dengan mula munculnya orientalisme khususnya setelah renaissance dan reformasi ajaran agama Kristen.

Pada mulanya agama Kristen menjadi motif utama kegiatan ini. Bahkan agamawan Kristen Protestan memandang perlu memberikan interpretasi baru terhaap teks-teks keagamaan mereka, agar sejalan dengan perkembangan baru. Sampai kemudian mereka mengarah ke Timur, dengan mempelajari bahasa Ibrani dan Arab. Sehingga studi mereka mencakup bahasa-bahasa Timur, agama dan kebudayaannya. Upaya agamawan ini disambut baik oleh politisi yang merasa gagal dalam invasi ke Timur yang dikenal dengan Perang Salib, makanya, sekian banyak agamawan bersekutu dengna penjajah. Akan tetapi tidak dapat dinafikan, bukan satu-satunya tujuan mereka menyebarkan agama dan menjajah, ada juga yang betul-betul bertujuan memenuhi hasrat kepada pengetahuan.

\footnotetext{
${ }^{38}$ Lihat, Hamid Fahmi Zarkasyi, pengantar dalam Islamia, Majalah Pemikiran dan Peradaban Islam (Jakarta: Khairul Bayan, 2003), vol. II, 4.

${ }^{39}$ Karel Stenbrink. "Berdialog dengan Karya-karya Kaum Orientalis." Jurnal Studi Alquran, 2, no. 2 (1996): 24.

${ }^{40}$ Faried F. Saenong. "Kesarjanaan Alquran di Barat; Studi Bibliografis.” Jurnal Studi Alquran, 2 , no. 2 (1996): 145.

${ }^{41}$ Southern menjelaskan bahwa Perang Salib antara Islam dan Kristen memberikan kontribusi terhadap kesalah pahaman Barat terhadap Islam. Lihat, Richard W. Southern, Western Views of Islam in the Middle Ages (Cambridge: Harvard Univerrsity, 1962), 28.

${ }^{42}$ Azim Nanji. "Introduction" dalam Azim Nanji (ed.), Mapping Islamic Studies: Genealogy, Continuity and Change (Berlin \&New York: Mouton de Gruyter, 1997), xi.

${ }^{43}$ Beberapa karya penelitian misalnya terlihat mengindikasikan hal tersebut misalnya bisa dilihat karya Arthur J. Arberry, The Koran Interpreted (London: Allen \& Uwin, 1955), 7, George Sale, The Koran: Translated into English (London: Frederick Warne, 1724), vii, W.M. Watt \&Richard Bell, Introduction to the Qur'an (Edinburgh: Edinburgh University Press, 1991), 173, 'Ali Qull Qara'i. "The Qur'an and Its Translator." Al-Tauhid, XII, no. 2 (1994).
} 
Dalam rangka memantapkan itu, maka, dibentuklah lembaga-lembaga pendidikan yang berkembang di Negara "penjajah" seperti di Inggris, Perancis, Belanda, Portugal dan lain-lain. Pada tahun 1636 Loud salah satu uskup kenamaan Inggris membentuk program studi (chair) di Universitas Oxford yang secara khusus mempelajari bahasa Arab. Kemudian berkembang pesat di berbagai Universitas dan Akademi di Inggris. Antara lain, London University (1916), lahir pula di Negara-negara jajahan Inggris Khurtum, Sudan dibentuk Gordon Memorial for Arabic Studies, di Afrika Selatan ada University of Cape Town (1918), di Pakistan Universitas Punjab, Dakka, Australia lahir Universitas Sydney, Melbourne, Queensland dan lain-lain. Tujuan yang ingin dicapai dari semua upaya itu adalah selain motifasi ilmiah, juga mempersembahkan sesuatu yang bermanfaat buat raja dan Negara melalui perdagangan, mengagungkan Tuhan, memperluas batas gereja, dan melakukan ajakan memeluk agama Kristen. ${ }^{44}$

Bahkan, Rodinson menelusuri sejarah orientalisme sejak abad ke-4 M., hingga pertengahan abad ke-20. ${ }^{45}$ Cetusan Gustav Weil (1808-1889 M.) melalui karyanya Historische-Kritische Einleitung in der Koran, ${ }^{46}$ pada tahun 1844. Asumsi yang dikembangkan Weil adalah bahwa dalam hal periodisasi Alquran ia membaginya ke dalam Makkiyah awal, tengah, akhir, serta Madaniyah. ${ }^{47}$

Di atas telah disinggung tentang pandangan sarjana muslim berkaitan dengan penentuan kronologis pada riwayat yang menjelaskan tartīb al-ayāt wa al-suwar, yang menarik untuk diungkap di sini bagaimana pandangan kesarjanaan barat, Montgomery Watt mengungkapkan bahwa para orientalis memusatkan perhatian pada pertimbangan gaya Alquran, perbendaharaan kata, mereka menjadikan Alquran sebagai sasaran penelitian dengan menggunakan metode kritik sastra dan kritik sejarah modern. ${ }^{48}$ Sedang dalam menetapkan pembagian surat-surat Alquran mereka tetap mengikuti pembagian oleh kesarjanaan muslim seperti yang telah diterangkan di awal. ${ }^{49}$

\footnotetext{
${ }^{44}$ Lihat Muammad Baha, al-Fikr al-Islamal-'adath wa 'ilatuh bi al-Isti 'mar al-Gharib(t.tp.: Maktabah Wahbah, 1991), 475-477. Lihat juga, M. Quraish Shihab.“Orientalisme.”25-27.

${ }^{45}$ Maxim Rodinson, Europe and the Mystique of Islam (London: Univ. of Washington Press, 1987), ix-x.Lihat pula, Ihsan Ali Fauzi."Orientalisme di Mata Orientalis Maxim Rodinson tentang Citra dan Studi Barat atas Islam.”Jurnal Ilmu dan Kebuayaan Ulumul Qur'an, III, no. 2 (1991): 6.

${ }^{46}$ Asumsi yang dipakai Weil dari para sarjana muslim ini kemudian diadopsi oleh Noldeke tahun 1860 dan Schwally pada tahun 1909, dalam karya monumentalnya Geschichte des Qoran dengan perubahan pada susunan kronologis surat-surat Alquran. karya bersama antara Noldeke dan Schwally ini memengaruhi Regis Blachere dalam membuat terjemahan Alqurannya yang berjudul Le Coran: Troduction Selon un Essai de Reclassement des Sourates (1949-1950). lihat George Tamir, Muqaddimah al-Tarjamah al-'Arabiyyah li Tarikh Alquran, (Bayrut: Konrad-Adenauer-Stiftung, 2004), xviii, Taufik Adnan Amal, Rekonstruksi Sejarah Alquran, 116-119, lihat pula, al-Waidi, Asbāb al-Nuzul, 21-23.

${ }^{47}$ Jane Dammen McAuliffe, Encyclopaedia of the Qur'an, (Leiden; Brill, 2001), 322, lihat pula Muammad 'Abid al-Jabir, Madkhal ila al-Qur'ān (Bayrut; Markaz Dirasat al-Wi'dah al-'Arabiyah, 2004), 240-241.

${ }^{48}$ W. Montgomery Watt, Bell's Introduction to the Qur'an, ( Edinburgh, Edinburg University Press, 2005), lihat juga: Taufik Adnan Amal, Rekonstruksi Sejarah Alquran, 116.

${ }^{49}$ Theodor Nöldeke, (Ed.) Freiderich Schwally, Tarikh al-Qur'an, terj.dan taqiqiGeorge Tamir, (Bayrut: Konrad-Adenauer-Stiftung, 2004), 60.
} 
Beberapa penulis dari kalangan ilmuwan Barat $^{50}$ dan orientalis membuat teori miring tentang Alquran di antaranya Theodor Noldeke penulis Geshichte des Qurans ${ }^{51}$ misalnya mengungkapkan anggapan bahwa Nabi Muhammad pernah lupa tentang wahyu sebelumnya, sedang pada tahun 1927, Alphonse Mingana pendeta Kristen asal Irak dan sekaligus guru besar di Universitas Birmingham Inggris, menegaskan bahwa Nabi Muhammad maupun masyarakat muslim tidak pernah menganggap Alquran secara berlebihan, kecuali setelah meluasnya negara Islam. Bahkan, cukup aneh John Burton murid Wansbrough mengklaim secara paradoks dan lebih dari semua klaim muslim tradisional, bahwa keseluruhan Alquran sekarang adalah karya nabi Muhammad sendiri.

Penolakan yang lebih tegas terhadap tesis Wansbrough pernah dilakukan oleh R.B. Sarjeant misalnya, menjelaskan intisari counter argument-nya terhadap Wansbrough dengan ungkapan "an historical circumstance so public, (karena sejarah pewahyuan Alquran tidak pernah terungkap).$^{52}$ Mereka, sekurang-kurangnya mempunyai pikiran bahwa kemungkinan ada gunanya memelihara ayat-ayat Alquran bagi generasi mendatang. Melakukan pendekatan terhadap permasalahan yang ada dari sudut pandang akal semata tidaklah cukup untuk menolak anggapan itu. ${ }^{53}$

Lebih lanjut Mingana menabuh genderang dengan mengumumkan statemen bahwa sudah tiba saatnya sekarang untuk melakukan kritik teks terhadap Alquran sebagaimana telah kita lakukan terhadap kitab suci Yahudi yang berbahasa Ibrani-

\footnotetext{
${ }^{50}$ Fazlur Rahman, guru besar kajian Islam di Universitas Chicago, mempunyai perhatian serius berkenaan dengan ilmuwan Barat dan kajian Alquran dengan upayanya memetakan literatur Barat dan kajian Alquran dalam abad modern ini menjadi tiga. Pertama: karya iru berusaha mencari titik temu dan titik pengaruh Yahudi-Kristen di dalam kajian Alquran, kedua: karya yang mengurai rangkaian kronologis dari ayat-ayat Alquran, dan ketiga: karya tersebut berupaya menerangkan Alquran baik secara holistic maupun parsial saja dari ayat Alquran. Lihat lebih lanjut Fazlur Rahman, Major Themes of the Quran, (Chicago, University of Chicago Press, 1980), xvi.

${ }^{51}$ Buku ini pertama kali terbit dengan bahasa Jerman pada tahun 1860 , oleh penerbit Gottingen. Dalam pelacakan peneliti, karya Noldeke ini diterbitkan pula oleh Leipzig Dicterich'sche Verlagsbuchhandlung, University of Toronto Library pada tahun 1919, kemudian karya ini dianggap yang paling penting dalam memberikan sumbangan berharga bagi kajian kronologi Qur'an. Edisi kedua dari buku ini direvisi dan diperluas oleh Schwally August Fascher, Gotthelf Bergsträsser dan Otto Pretzl. Terbit dalam tiga jilid pada tahun 1909, 1919 dan 1938, dan dicetak ulang dengan proses foto kopy pada tahun 1961, di terjemahkan dan ditaqiqi pula oleh George Tamir dengan judul Tarikh al-Qur'an. Karya Nöldeke ini terus dikembangkan bersama Schwally, Bergsträsser, dan Otto Pretzl, dan ditulis selama 68 tahun sejak edisi pertama. Hasilnya, sampai saat ini, Geschichte des Qorans menjadi karya standar bagi para orientalis khususnya dalam sejarah kritis penyusunan Alquran.lihat lebih lanjut, W. Montgomery Watt, Bell's Introduction to the Qur'an, (Edinburgh, Edinburg Universitu Press, 2005), 109-110, lihat pula Rudi Paret, The Study of Arabic and Islam at German Universities: German Orientalist Since Theodor Nöldeke, (Weisbaden; Franz Steiner, 1968), 13-14, Theodor Nöldeke, (Ed) Friedrich Schwally, Tarikh al-Qur'an, terj. DantahqiqGeorge Tamir, (Bayrut: Konrad-Adenauer-Stiftung, 2004), George Tamir, Muqaddimah alTarjamah al-'Arabiyyah li Tarikh al-Qur'an, (Bayrut: Konrad-Adenauer-Stiftung, 2004), xi.

${ }^{52}$ Perdebatan imiah yang ringkas dan tegas tentang penolakan terhadap metodologi Wansbrogh, lihat Fazlur Rahman, Major Themes of the Qur'an, (Chicago, University of Chicago Press, 1980), Fazlur Rahman, Aproaches to Islam in Religion Studies, dalam R.C. Martin (ed.), Aproaches to Islam in Religion Studies, (Arizona, 1985), 189-202, lihat juga Fazlur Rahman, "Some Recent Books on the Qur'an by Western Authors.” Journal of Religion, 61, no. 1, (Januari, 1984): 73-95.

${ }^{53}$ M.M. Al-'A'am, The History of The Qur'anicText, 56.
} 
Arami dan kitab suci Kristen yang berbahasa Yunani (The time has surely come to subject the text of the Koran to the some criticism as that to wich we subject the Hebrew and Aramaic of The Jewish Bible, and the Greek of the Christian Scriptures). ${ }^{54}$

Genderang yang ditabuh Mingana di atas, kendati menyesatkan, namun tidak serta merta ditanggapi dengan membabi buta, namun harus pula ditanggapi secara ilmiah. Entah karena apa Mingana mengungkapkan seperti itu, ${ }^{55}$ peneliti menduga bahwa pernyataan di atas keluar akibat dari kitab suci mereka yang diyakini mereka sebagai kitab suci yang dianggap sudah banyak campur tangan manusia, sebagaimana cendekiawan Kristen telah lama meragukan otentisitas Bibel. ${ }^{56}$ Pernyataan di atas, ternyata cukup memikat, sehingga banyak diikuti oleh orientalis belakangan lainnya.

Mingana tercatat bukan orang yang pertama kali melontarkan gagasan semacam itu, dan ia juga tidak sendirian. Ternyata, jauh sebelum Mingana tahun 1834, Gustav Fluegel seorang orientalis Jerman, tepatnya di Leipzig. Fleugel menerbitkan mushaf hasil renungan dan kajian filologinya, dan karya itu dikenal dengan Corani Textus Arabicus. Baru kemudian datang Noldeke. ${ }^{57}$

Dalam satu artikel Encyclopedia Britannica (1891) Noldeke, tokoh orientalis, menyebutkan banyak kekeliruam di dalam Alquran. Karena kejahilan Muhammad kata Noledeke tentang sejarah awal agama Yahudi, kecerobohan nama-nama dan perincian yang lain, yang ia curi dari sumber-sumber Yahudi. ${ }^{58}$ Ada ungkapan Noldeke yang perlu disimak misalnya, dia mengatakan bahkan orang yahudi yang paling tolol sekalipun tidak pernah salah menyebut Haman (menteri Ahasuerus) untuk menteri Fir'aun, ataupun menyebut Miriam saudara perempuan Musa dengan Maryam (Miriam) ibunya al-masih... (dan) dalam kebodohannya tentang sesuatu di luar tanah

\footnotetext{
${ }^{54}$ Syamsuddin Arif, “Alquran,Orientalisme dan Luxenberg”.dalam Al-Insan, Jurnal Kajian Islam, Depok: Lembaga kajian dan Pengembangan Islam, Gema Insani, 1, no. 1, (Januari, 2005): 9-10.

${ }^{55}$ Hamka mengutip pendapat 'Al'usn al-Kharbu'y, Guru Besar di 'Ayn Syams, Mesir, menyebutkan, bahwa ada tiga tujuan orientalisme di dunia Islam, yaitu (1) Untuk penyebaran agama Kristen ke negerinegeri Islam, (2) Untuk kepentingan penjajahan, (3) Untuk kepentingan ilmu pengetahuan semata.Hamka, Studi Islam, (Jakarta: 1985), 12. Lihat pula, Catatan Akhir Pekan Adian Husaini, Kajian Orientalis di UIN Jakarta, (akses 27 Aril 2010); didapatkan dari www.hidayatullah.com.

${ }^{56}$ Ada hasil penelitian seminar yang cukup mengejutkan yang dilakukan oleh 76 ahli dalam berbagai disiplin keilmuan dari berbagai Universitas terkenal di dunia, yang dirangkum dalam buku yang berjudul The Five Gospels: What did Jesus Really Say? The Search for the Authentic Words of Jesus, yang dialihbahasakan dan dikomentari oleh Robert W. Funk, Roy W. Hoover dan Jesus Seminar. Dalam teks itu diberi tanda sebagai symbol yaitu merah (red): that Jesus, pink: sure sounds like Jesus, Grey: well, maybe, black: Jesus did not say this there been some mistaken. Dan kesimpulan akhir para ahli dari seluruh dunia dalam seminar tentang ucapan Yesus dalam Injil mengatakan "eighty two percent of the words ascribed to Jesus in the gospel werw not actually spoken by him, according to the Jesus seminar" (delapan puluh dua persen yang dianggap ucapan Yesus dalam Injil, sesungguhnya tidak diucapkan Yesus, menurut seminar tentang Yesus).

${ }^{57}$ Syamsuddin Arif, “Alquran, Orientalisme dan Luxenberg."11.

${ }^{58}$ Lihat, Ibn Waraq (ed.), The Origins of The Koran: Classic Essays on Islam's Holy Book, (Prometheus Book, Amherst, NY, 1998), 36-63, lihat pula Mu'afá 'A'am, mengutip artikel di Encyclopedia Britannica (1891), ia paparkan bahwa Nöldeke menyebutkan banyaknya kekeliruan dalam Al-Quran karena, kata Nöldeke, "Kejahilan Muhammad" tentang sejarah awal agama Yahudi-kecerobohan namanama dan perincian yang lain yang ia curi dari sumber-sumber Yahudi." Kemudian, 'A'ammembuktikan sejumlah kesalahan fatal kajian Noldeke tentang Al-Quran.Mu'afá 'A'am, The History of The Qur'anic Text, 341 .
} 
Arab, ia menyebutkan suburnya negeri Mesir di mana hujan hampir-hampir tidak pernah kelihatan dan tidak pernah hilang karena hujan dan bukan karena kebanjiran yang disebabkan oleh sungai Nil." ${ }^{59}$

Dari pemaparan di atas, jelas Noldeke seolah mengada-ada, dipandang dari segi logika bagaimana mungkin Nabi lupa dalam menyampaikan ayat yang langsung disampaikan dari Allah melalui sentuhan malaikat Jibril. Jibril inilah yang selalu mengawal dan membimbing Nabi, bahkan kema'shuman Nabi tidak bisa dielakkan, dalam memelihara ingatan Nabi Muhammad secara konsisten malaikat Jibril berkunjung setiap tahun, yang dengan sendirinya membantah pandangan Noldeke di atas. Kalaupun dalam sejarah kodifikasi Alquran, Zayd bin Thabit selaku sekertaris pencatat Alquran pernah kehilangan dua ayat terakhir surat Bara'ah, namun berkat kecermatan dan ketepatannya akhirnya dua ayat yang hilang bisa ditemukan dari mushaf Hafsah. Selanjutnya, Mingana dalam pendapatnya di atas, nampaknya keliru. Dikatakan demikian karena Alquran baik di mata Nabi maupun sahabat adalah wahyu yang agung, bahkan setiap ayat turun kepada Nabi ada sahabat yang menulisnya melalui beberapa media, ada pula yang langsung menghafalnya dalam hati mereka. Sehingga, Alquran dalam perjalanan sejarahnya bahkan hingga kini, tetap terjaga keaslian dan kemurniaannya. Bahkan, dalam beberapa redaksi Alquran menggunakan kosakata tal, yutl, atl, tatl, dan yatlseperti pada Q.S. 2: 129 dan 151, 3: 164, 22: 45, dan 62: 2 . Kesemua maknanya mengandung isyarat akan peranan Nabi dalam mengenalkan langsung kepada ummatnya.

Hal lain yang tidak luput dari kritikan para orientalis adalah berkenaan perbedaan ragam bacaan dalam Alquran. Menurut penelitian MM. Al-'A'amterdapat lebih dari 250,000 naskah Alquran dalam bentuk manuskrip, secara lengkap maupun sebagiansebagian, hingga abad hijriah sampai hari ini. Kesalahan-kesalahan yang fatal sesungguhnya pernah dikaji dalam lingkungan akademik pada dua kelompok disengaja atau tidak, dan dalam jumlah manuskrip yang banyak ini, secara manusia mungkin saja masih ada kekurangan-kekurangan dan celah, untuk mengatakan kurang sempurna. Beberapa karya tulis yang mengupas masalah ini misalnya sebagai berikut: (1) Ernst Wurtwein, The Text of The Old Testament, edisi kedua yang telah direvisi dan diperluas, William B. Eerdmans publishing company, Grand rapids, Michigan, 1995; (2) Bart D. Ehrman, The Ortodox Corruption of Scripture, Oxford Univ. Press, 1993; dan (3) Bruce M. Metzger, The Text of The New Testament, Edisi ketiga, Oxford Univ. Press, 1992. ${ }^{60}$

Buku pertama tentang Perjanjian Lama dan yang lainnya Perjajian Baru, dan kesemuanya mengelompokkan tentang kesalahan. Hanya saja, nampaknya kurang tepat bila perlakuan seperi itu dilakukan pula pada Alquran. Kalaupun menurut mereka penulisan Alquran terdapat kesalahan, maka di mana letak kesalahannya? Apakah

\footnotetext{
${ }^{59}$ Teodor Noldeke, The Koran, dalam Ibn Waraq (ed.), The Origins of The Koran: Classic Essays on Islam's Holy Book, 43.

${ }^{60}$ M.M. Al-'A”am, The History of The Qur'anicText, 167.
} 
dilakukannya dengan sengaja atau tidak. Baiklah coba kita akan urai kejelasannya. Secara jujur kita akui sebelum terjadi seperti mushaf yang kita pegang sekarang, Alquran atau tepatnya teks Alquran betul-betul masih belum terdapat tanda baca, tanda titik dan bentuk huruf lainnya.

Goldziher sebagaimana dikutip M.M. 'A'ammenanggapi perbedaan bacaan dalam Alquran adalah kekeliruan dalam penulisan bahasa Arab zaman dulu, tidak ada titik dan tanda diakritikal. Oleh karena itu Goldziher lebih menajamkan analisisnya dengan membuat contoh, bentuk kata fiīl saat dibuang tanda titiknya memungkinkan lahirnya ragam bacaan seperti: , ini berarti dia telah dibunuh seekor gajah sebelum mencium bagian depan seperti yang telah disebut. ${ }^{61}$

Selain beberapa tokoh di atas, Sir William Muir (1819-1905 M), menyodorkan upayanya menyusun surah berdasarkan kronologi pewahyuan Alquran tentang biografi Nabi dalam karyanya Life of Mohamet (1858-1861 M.), yang dimuat dalam essei mengenai: Sourches for the Biography of Mohamet" dan ia mengungkapkan lebih lengkap dalam The Coran, its Composition and Teaching; and the Testimony it Bears to the Holy Scriptures. Muir mengajukan suatu aransemen kronologi surat-surat Alquran yang dikelompokkan pada enam periode, lima periode Mekkah dan satu periode Madinah. Muir menyebutkan 93 surat Makkiyah dan 21 Madaniyah. ${ }^{62}$

Kemudian pada tahun 1937 muncul orientalis asal Australia yang pernah mengajar di American University, Cairo dan menjadi guru besar di Columbia University, Arthur Jefferi yang berupaya mendekonstruksi mushaf 'Uthmani dengan upayanya membuat mushaf baru. Hal ini berdasar pada kitab al-ma'arif karya Ibn Abu Dawud al-Sijastan, yang ia anggap sebagai bacaan-bacaan dalam mushaf tandingan, yang dalam istilah Jeffery ia sebut rival codices. ${ }^{63}$ Usaha kerasnya ini merupakan kelanjutan dari upaya Gothelf Bergstraesser dan Otto Pretzl, keduanya ini yang mengumpulkan foto-foto lembaran manuskrip Alquran dengan membuat edisi kritis, tetapi upayanya ini gagal karena dokumen-dokumennya terbakar pada peristiwa Perang Dunia ke-II. ${ }^{64}$

\footnotetext{
${ }^{61}$ M.M. al-'A'am, The History of The Qur'anicText, 168.

${ }^{62}$ Sir William Muir, The Life of Mahomet and History of Islam to the Era of the Hegira: with Introductory Chapters on the Original Sourches for the Biography of Mahomet and on the Pre-Islamite History of Arabia, (London, Smith, Elder and Co, 1981), 2, The Cöran, its Composition and Teaching; and the Testimony it Bears to the Holy Scriptures, ( New York; E. \& J. B. Young \& Co), 37, 43, lihat pula Theodor Noldeke, (Ed) Friedrich Schwally, Tarikh al-Qur'an, 66-67, M. Watt, Bell's Introduction to the Qur'an, 212, Taufik Adnan Amal, Rekonstruksi Sejarah Alquran, 125-127, Taufik Adnan Amal \&Sumsu Rizal Panggabean, Tafsir Kontekstual Alquran: Sebuah Kerangka Konseptual, (Bandung: Mizan, 1989).

${ }^{63}$ Arthur Jefferi, Materials for The History of The Text of the Quran: The Old Codices, (Leiden: E.J. Brill, 1937, akses 27 April 2010); didapatkan dari http:/www.bible.ca/islam/library/Jeffery/thq.htm.

${ }^{64}$ Arthur Jefferi, The Quran as Scripture, (New York: R.F. Moore Co., 1952, akses 27 April 2010); yang berasal dari ceramah bertajuk The Textual History of The Quran, yang disampaikan pada 31 Oktober 1946 di sebuah pertemuan the middle east society of Jarussalem, Israel. Didapatkan dari http://www.bible.ca/islam/library/Jeffery/thq.htm.
} 


\section{Kesimpulan}

Dari semua upaya-upaya itu, terlihat begitu besar ketertarikannya orientalis terhadap kajian Alquran, terlepas usaha keras itu ingin merekonstruksi Alquan, yang

pasti dari kajian mereka kita kembali dikejutkan untuk selalu menjaga dan paling tidak selalu mengakaji Alquran. Maka upaya apapun, baik misalnya perdebatan nasikhmansukhmenyoal adanya surat tambahan versi Syi'ah, ingin merombak susunan ayat dan surat Alquran secara kronologis, mengoreksi bahasa Alquran ataupun ingin mengubah redaksi ayat-ayat tertentu, bahkan bukan hanya sampai di situ menebar isu mempersoalkan autentisitas Alquran, dan lain-lain. Jelasnya, stigma miring ini tidak kemudian melunturkan keimanan atau memurtadkan keyakinan, karena upaya mereka terbukti sampai sekarang tidak berhasil. Justru malah sebaliknya, animo untuk mengkaji Alquran dan keyakinan akan kitab suci Alquran semakin tinggi dan marak. 


\section{DAFTAR PUSTAKA}

Al-'A'am, M.M., The History of The Qur'anicText From Revelation to Compilation A Comparative Study The Old and New Testamenth, (Sejarah Teks Al-Qur' $n$ dari Wahyu Sampai Kompilasi: Kajian Perbandingan dengan Perjanjian Lama dan Perjanjian Baru, terj. Sohirin Solihin et. All. (Jakrta: Gema Insani Press, 2005

al-'Aqiqi, Najib, al-Mustshriqūn (Mesir: D's'r al-Ma'arif, t.th.

al-Jabir, Muhammad 'Abid,Madkhal ila al-Qur'ān (Bayrut; Markaz Dirasat al-Wihdah al-'Arabiyah, 2004), 240-241.

al-Mâlikî, Muhammad 'Alawî, Mauqifu al-Muslîm min al-Dirâsat al-Istisyrâqiyah (Kairo: Mathba'ah Hasan, tt.

‘Ali Qull Qara'i. ”The Qur'an and Its Translator.” Al-Tauhid, XII, no. 21994

al-Sufyân, Âbir bin Muhammad, al-Mustasyriqûn wa man Tâbi'ahum wa Maiqufuhum min Stabât al-Syarî'ah wa Syumûlaha Dirasatan wa Tatbiqan (Makkah: Maktabaah al-Manarah, 1988

al-Zayadi, Muhammad Fathullah, al-Istisyrâq Ahdâfuhu wa Wasâiluhu (SyiriaLibanon: Dâr Qutaibah, 2002

Arberry, Arthur J., The Koran Interpreted (London: Allen \& Uwin, 1955), 7, George Sale, The Koran: Translated into English (London: Frederick Warne, 1724

Arif, Syamsuddin, "Alquran,Orientalisme dan Luxenberg".dalam Al-Insan, Jurnal Kajian Islam, Depok: Lembaga kajian dan Pengembangan Islam, Gema Insani, 1, no. 1, (Januari, 2005): 9-10.

Armas, Adnin, Metodologi Bibel dalam Studi Alquran (Jakarta: Rajawali Grafindo Persada, 1996

Arthur Jefferi, Materials for The History of The Text of the Quran: The Old Codices, (Leiden: E.J. Brill, 1937, didapatkan dari http://www.bible.ca/islam/library/Jeffery/thq.htm.

Arthur Jefferi, The Quran as Scripture, (New York: R.F. Moore Co., 1952, akses 27 April 2010); yang berasal dari ceramah bertajuk The Textual History of The Quran, yang disampaikan pada 31 Oktober 1946 di sebuah pertemuan the middle east society of Jarussalem, Israel. Didapatkan dari http://www.bible.ca/islam/library/Jeffery/thq.htm.

Baha, Muhammad, al-Fikr al-Islamal-'adath wa 'ilatuh bi al-Isti'mar al-Gharb (t.tp.: Maktabah Wahbah, 1991

Badawi, 'Abdal-Rahman, Mawsū'ah al-Mustasyriqūn (Bayrut: Dār al-'Ilm al-Maliyun, 1993).

Buchori, Didin Saefuddin, "Runtuhnya Sendi-Sendi Orientalisme Dalam Kajian Islam", diakses dari http://www.ulil-albab.uika-bogor.ac.id/berita-134runtuhnya-sendisendi-orientalisme-dalam-kajian-islam.html, Jumat, 09 November 2012;

Buchori, Didin Saefuddin, "Runtuhnya Sendi-Sendi Orientalisme Dalam Kajian Islam" diakses dari http://www.ulil-albab.uika-bogor.ac.id/berita-134-runtuhnyasendisendi-orientalisme-dalam-kajian-islam.html"; 
el-Badawiy, Hasan Abdul Rauf M. dan Abdurrahman Ghirah, Orientalisme dan Misionarisme : Menelikung Pola Pikir Umat Islam (Bandung: PT. Remaja Rosdakarya, 2007

el-Maidani, Abdurrahman Hasan, Ajnihatu-1 Mukr ats-Tsalasah, (Bayrut, Dâr alQalam, 1980 M.

Farhan, Ahmad, "Orientalisme Alquran: Studi Pemikiran Abraham Geiger" dalam Orientalisme Alquran dan Hadis(Yogyakarta: Nawesea Press, 2007

Farhan, Ahmad, "Orientalisme Alquran: Studi Pemikiran Abraham Geiger", 62-63.

Fauzi, Ihsan Ali. "Orientalisme di Mata Orientalis Maxim Rodinson tentang Citra dan Studi Barat atas Islam.”Jurnal Ilmu dan Kebuayaan Ulumul Qur'an, III, no. 2 (1991): 6.

Hamka, Studi Islam, (Jakarta: Pustaka Panjimas, 1985

Hidayat, Nuim, Imperialisme Baru (Jakarta : Gema Insani Press, 2009), h. 51.

Husaini, Adian, "Kajian Orientalis di UIN Jakarta" diakses dari http://insistnet.com/index.php?option=com_content\&view=article\&id=71:kajia n-orientalis-di-uin-jakarta\&catid=1:adian-husaini, Jumat, 09 November 2012.

Ibn Waraq (ed.), The Origins of The Koran: Classic Essays on Islam's Holy Book, (Prometheus Book, Amherst, NY, 1998

Ibn Warraq, The Origins of The Qur'an, Essays on Islam's Holy Book (New York: Prometheus Books, 1998

Ibnu Warraq, Why I Am Not a Muslim (New York: Prometheus Books, 1995

Jakub, Tk. H. Ismail, Orientalisme dan Orientalisten (Surabaya: C.V. Faizan, tt.

Jamilah, Maryam, Islam dan Orientalisme : Suatu Kajian Analitik (Jakarta : PT. RajaGrafindo Persada, 1994), h. 1.

Jeffery, Arthur, Materials for the History of The Text of The Quran, The Old Codices (Leiden: E.J. Brill, 1937).

Jeffery, Arthur, The Textual History of The Qur'an, (diakses 27 April 2010); diambilkan dari http://www.bible.ca/-islam/library/Jeffery/thq.htm.

Lestari, Kartika Pemilia, "Sejarah Islam di Mata Orientalis - Studi Kritis terhadap Buku Islam and The West : A Historical Cultural Survey karya Philip K. Hitti" dalam

http://www.inpasonline.com/index.php?option=com_content\&view=article\&id $=1011$ :sejarah-islam-di-mata-orientalis--studi-kritis-terhadap-buku-islam-andthe-west--a-historical-cultural-survey-karya-philip-k-hitti\&catid=28:sejarahperadaban-islam\&Itemid $=97$,

M. Quraish Shihab. “Orientalisme.”Jurnal Studi al-Qur'ân, 1, no. 2(2006): 21.

Manzoor, S. Parvez. "Method Vis A Vis Truth: Orientalisme dan Studi al-Qur'ân." Jurnal Studi al-Qur'ân 1, no. 2 (2006): 46.

McAuliffe, Jane Dammen, Encyclopaedia of the Qur'an, (Leiden; Brill, 2001

Muir, Sir William, The Life of Mahomet and History of Islam to the Era of the Hegira: with Introductory Chapters on the Original Sourches for the Biography of Mahomet and on the Pre-Islamite History of Arabia, (London, Smith, Elder and Co, 1981), 2, The Cöran, its Composition and Teaching; and the Testimony it Bears to the Holy Scriptures, ( New York; E. \& J. B. Young \& Co

Nanji, Azim. "Introduction" dalam Azim Nanji (ed.), Mapping Islamic Studies: Genealogy, Continuity and Change (Berlin \&New York: Mouton de Gruyter, 1997), xi. 
Nasaruddin Umar. "Alquran di Mata Mantan Intelektual Muslim: Ibn Warraq dan Mark A. Gabriel”. Jurnal Studi al-Qur'ân, 1, No. 2 (2006): 87-132.

Noldeke, Teodor, The Koran, dalam Ibn Waraq (ed.), The Origins of The Koran: Classic Essays on Islam's Holy Book, 43. Tamir, (Bayrut: Konrad-Adenauer-Stiftung, 2004

Noorhayatie, Siti Mahmudah, "Hadith Di Mata Orientalis (Studi Kritis Atas Pemikiran Ignaz Goldziher Tentang Penulisan Hadith)" diakses dari http://jurnalushuluddin.wordpress.com/.

Paret, Rudi, The Study of Arabic and Islam at German Universities: German Orientalist Since Theodor Nöldeke, (Weisbaden; Franz Steiner, 1968

Prasetyo, Hendro, "Pembenaran Orientalisme Kemungkinan dan Batas-batasnya," dalam ISLAMIKA Jurnal Dialog Pemikiran Islam (Bandung: Mizan, 1994

Rahman, Fazlur, "Some Recent Books on the Qur'an by Western Authors." Journal of Religion, 61, no. 1, (Januari, 1984)

Rahman, Fazlur, Aproaches to Islam in Religion Studies, dalam R.C. Martin (ed.), Aproaches to Islam in Religion Studies, Arizona, 1985

Rahman, Fazlur, Major Themes of the Quran, (Chicago, University of Chicago Press, 1980

Rahman, Fazlur, Major Themes of the Qur'an, (Chicago, University of Chicago Press, 1980

Rais, M. Amien, Cakrawala Islam, Bandung: Mizan, 1986.

Rodinson, Maxim, Europe and the Mystique of Islam (London: Univ. of Washington Press, 1987

Saenong, Faried F.."Kesarjanaan Alquran di Barat; Studi Bibliografis."Jurnal Studi Alquran, 2, no. 2, 1996

Said, Edward W., Orientalisme, terj. Asep Hikmat (Bandung: Pustaka, 1996

Said, Hasani Ahmad, Diskursus Munasabah Alquran (Jakarta: Puspita Press, 2011

Setiawan, Nur Kholis, "Orientalisme Alquran: Dulu, Kini dan Masa Datang, dalam Orientalisme Alquran dan Hadis, Yogyakarta: Nawesea Press, 2007

Smith, Huston, The World's Religions (Sanfransisko: Harper Collins Publisher, 1991

Sou'yb, Joesoef ,Orientalisme dan Islam, Jakarta: Bulan Bintang, 1985

Southern, Richard W., Western Views of Islam in the Middle Ages, Cambridge: Harvard Univerrsity, 1962

Stenbrink, Karel. "Berdialog dengan Karya-karya Kaum Orientalis."Jurnal Studi Alquran, 2, no. 21996

Tamir, George, Muqaddimah al-Tarjamah al-'Arabiyyah li Tarikh al-Qura'ān: Bayrut: Konrad-Adenauer-Stiftung, 2004

Tamir, George, Muqaddimah al-Tarjamah al-'Arabiyyah li Tarakh Alquran, (Bayrut: Konrad-Adenauer-Stiftung, 2004),

Taufik Adnan Amal \&Sumsu Rizal Panggabean, Tafsir Kontekstual Alquran: Sebuah Kerangka Konseptual, Bandung: Mizan, 1989

Waardenburg, J.D.J., "Mustashrikun" dalam C.E. Boswort dan E. Van Donzel (ed.), The Encyclopedia of Islam,Leiden: E.J. Brill, 1993

Watt, W. Montgomery, Bell's Introduction to the Qur'an, Edinburgh, Edinburg University Press, 2005. 
Watt, W.M. \&Richard Bell, Introduction to the Qur'anEdinburgh: Edinburgh University Press, 1991

Wizan, Adnan M., Akar Gerakan Orientalisme Dari Perang Fisik Menuju Perang Fikir, terj. Ahmad Rafiq Zainul Mun'im dan Fathurrahman, Yogyakarta: Fajar Pustaka, 2003

Zaqzuq, Mahmud Hamdi, al-Istishrâq wa al-Khalfiyyah al-Fikriyyah li al-Sirâ' alHadâra, tt: tp, 1988

Zarkasy, Hamid Fahmy, Mengkritisi Kajian Islam Orientalis, Pengantar, Majalah Islamia, Volume II No. 3, Desember 2005.

Zarkasyi, Fahmi, "Tradisi Orientalisme dan Framework Studi Alquran" dalam http://tsaqafah.isid.gontor.ac.id/volume-vii-1/tradisi-orientalisme-danframework-studi-Alquran.html", diakses pada Jumat, 9 November 2012.

Zarkasyi, Hamid Fahmi, pengantar dalam Islamia, Majalah Pemikiran dan Peradaban Islam (Jakarta: Khairul Bayan, 2003), vol. II, 4.

Zayd, Nasr Hamid Abu,Al-Quran, Hermeneutik dan Kekua-saan: Kontroversi dan Penggugatan Hermeneutik Al-Quran, Jakarta: Rqis, 2003 